\title{
Do we really understand what happens to valve allografts?
}

\author{
J. F. Matthias Bechtel, MD
}

From the Department for Cardiothoracic Surgery, University Hospital Bergmannsheil, Bochum, Germany.

Disclosures: Author has nothing to disclose with regard to commercial support.

Received for publication April 18, 2016; accepted for publication April 19, 2016; available ahead of print June 8, 2016.

Address for reprints: J. F. Matthias Bechtel, MD, Klinik fuer Herz- und Thoraxchirurgie, Berufsgenossenschaftliches Universitaetsklinikum Bergmannsheil GmbH, Ruhr-Universitaet Bochum, Buerkle-de-la-Camp-Platz 1, 44789 Bochum, Germany (E-mail: matthias.bechtel@bergmannsheil.de).

J Thorac Cardiovasc Surg 2016;152:1200-1

$0022-5223 / \$ 36.00$

Copyright $(2016$ by The American Association for Thoracic Surgery

http://dx.doi.org/10.1016/j.jtcvs.2016.04.059

The article by Helder et $\mathrm{al}^{1}$ demonstrates that the modes of failure of decellularized aortic valve allografts (DAVAs) do not necessarily differ from standard cryopreserved allograft valves (SCAVs). The authors followed 42 patients who had received a DAVA that was commercially available and decellularization and sterilization had been achieved by a proprietary process (Cryolife Inc, Kennesaw, Ga). The authors found an increase in the rate of reoperation beyond 5 years after implantation. ${ }^{1}$ At the time of the study, $37 \%$ of survivors had undergone reoperation.

What makes this article interesting is not the comparison with a group of patients who had received SCAV. In fact, the little that we know about the 2 groups suggests that they differ significantly and should not be compared. The interesting finding is that the pathologic analyses of 10 DAVAs revealed scarce recellularization in only a minority of patients, edemateous degeneration and calcification in almost all cases, and evidence of adventitial fibrosis and neointimal fibroplasia in all cases. These findings appear not to differ from reports about the modes of failure of $\mathrm{SCAV},{ }^{2,3}$ and the reoperation rates are not low (estimated freedom from reoperation at 10 years was $51 \%$ ).

Therefore, these data question our expectation that DAVAs are better than normal ones. Where do these expectations come from?

In the 1990s it was shown that implantation of cryopreserved allograft valves elicit a donor-specific cellular and humoral immune response. ${ }^{4,5}$ Given this fact, it appeared logical that decellularization would hamper this response. Several clinical reports supported this hypothesis. ${ }^{6-8}$ However, little was known about the late fate of DAVAs, especially in the aortic position. In the pulmonary valve position, the available evidence does not suggest that decellularized allografts have lower long-term reoperation rates. $^{9,10}$ In addition, it has not conclusively been demonstrated in clinical settings that the donor-specific immune response against allograft valves is indeed responsible for their degeneration.

Does all that mean that decellularization was a useless idea? I believe we simply do not know.

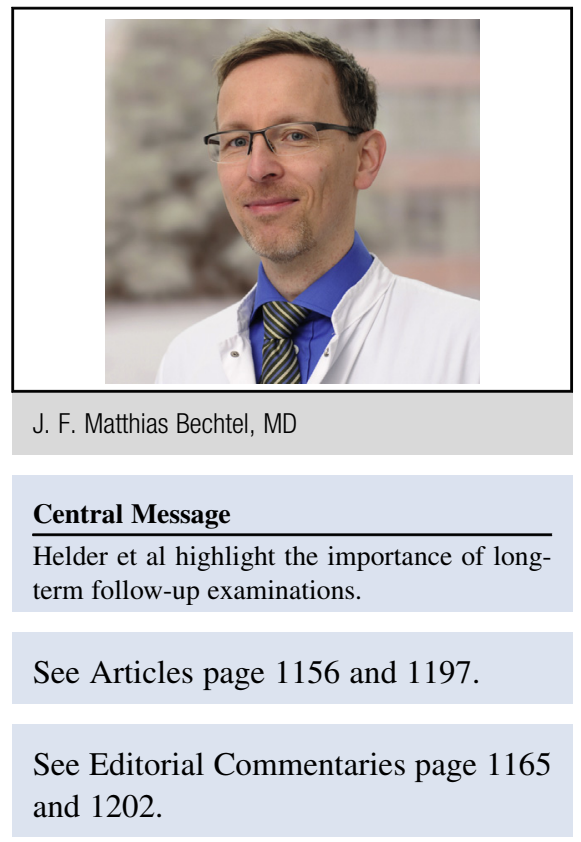

Decellularization - as briefly discussed by Helder et $\mathrm{al}^{1}$ can be achieved by different processes. Sterilization and preservation are 2 more steps that necessarily follow. All of these steps can induce damage that might finally result in degeneration and the need for reoperation. Probably these later steps induce damage that is more important than rejection of the relatively small number of viable donor cells found in SCAV. Some recent evidence for this hypothesis comes from the observation that "fresh" DAVAs in the pulmonary position appear to perform better than normal or decellularized cryopreserved allograft valves. ${ }^{10}$

Biology is complex and difficult to understand. Measures developed to overcome problems can induce new and unexpected problems that sometimes only manifest late after an operation. Therefore, the central message of the article by Helder et al $^{1}$ that "new tissue engineered valves should be studied longer term before use is widespread" has to be fully supported.

\section{References}

1. Helder MRK, Kouchoukos NT, Zehr K, Dearani JA, Maleszewski JJ, Leduc C, et al. Late durability of decellularized allografts for aortic valve replacement: a word of caution. J Thoracic Cardiovasc Surg. 2016;152:1197-9.

2. Mitchell RN, Jonas RA, Schoen FJ. Pathology of explanted cryopreserved allograft heart valves: comparison with aortic valves from orthotopic heart transplants. J Thorac Cardiovasc Surg. 1998;115:118-27.

3. Koolbergen DR. The pathology of aortic and pulmonary homograft valves. Leiden: Universiteit Leiden; 2003.

4. Smith JD, Ogino H, Hunt D, Laylor RM, Rose ML, Yacoub MH. Humoral immune response to human aortic valve homografts. Ann Thorac Surg. 1995; 60(Suppl):S127-30. 
5. Hoekstra F, Knoop C, Vaessen L, et al. Donor-specific cellular immune response against human cardiac valve allografts. J Thorac Cardiovasc Surg. 1996;112: 281-6.

6. Elkins RC, Dawson PE, Goldstein S, Walsh SP, Black KS. Decellularized human valve allografts. Ann Thorac Surg. 2001;71(Suppl):S428-32.

7. Bechtel JFM, Müller-Steinhardt M, Schmidtke C, Brunswick A, Stierle U, Sievers HH. Evaluation of the decellularized pulmonary valve homograft (SynerGraft $^{\mathrm{TM}}$ ). J Heart Valve Dis. 2003;12:734-40.
8. Zehr KJ, Yagubyan M, Connolly HM, Nelson SM, Schaff HV. Aortic root replacement with a novel decellularized cryopreserved aortic homograft: postoperative immunoreactivity and early results. J Thorac Cardiovasc Surg. 2005;130:1010-5.

9. Bechtel JFM, Stierle U, Sievers HH. 52 months mean follow-up of decellularized SynerGraft ${ }^{\mathrm{TM}}$-treated pulmonary valve allografts. J Heart Valve Dis. 2008;17:98-104.

10. da Costa FD, Takkenberg JJ, Fornazari D, et al. Long-term results of the Ross operation: an 18-year single institutional experience. Eur J Cardiothorac Surg. 2014;46:415-22. 